\title{
Wyniki i organizacja produkcji W gospodarstwach rolniczych o różnych formach organizacyjno-prawnych
}

\section{Wprowadzenie}

Na obecnym etapie rozwoju gospodarczego działalność produkcyjną w rolnictwie prowadzą podmioty gospodarcze o różnej formie prawnej i strukturze własności. W rolnictwie, w odróżnieniu od działalności przemysłowej i handlowej, ze względu na specyfikę tego działu produkcji, wpływ formy organizacyjno-prawnej na efekty ekonomiczne jest bardziej złożony. $Z$ formą własności wiąże się charakter pracy. W rolnictwie większości krajów świata dominującą formą podmiotów rolniczych są gospodarstwa rodzinne, których wielkość łączy się najczęściej z potencjałem pracy rodziny, a ziemia nie zawsze w całości musi być jej własnością. Cechą dominującą tej formy gospodarstw jest praca własna, a praca najemna ma charakter uzupełniający. $W$ tej formie gospodarstw występują partnerskie stosunki pracy: Druga forma gospodarstw oparta jest na pracy najemnej. Mogą to być wielkoobszarowe gospodarstwa prywatne lub z ziemią dzierżawiona. Takie gospodarstwa występowały w Polsce $w$ okresie międzywojennym i wcześniej. Obecnie występują $w$ formie dzierżaw prowadzonych przez osoby fizyczne lub rzadziej jako gospodarstwa z własną ziemia. Inny typ gospodarstw z pracą najemną (wykonawczą i kierownicza) stanowią przedsiębiorstwa państwowe. Ta forma przedsiębiorstw była rozwijana w Polsce w okresie powojennym do $1990 \mathrm{r}$. Obecnie w niewielkim zakresie występuje w formie jednoosobowych spółek Agencji Własności Rolnej Skarbu Państwa (AWRSP) ${ }^{1}$. W procesie restrukturyzacji gospodarstw Skarbu Państwa część nieruchomości (głównie w postaci zorganizowanych gospodarstw rolnych, przetwórczych lub usługowych) została przekazana

\footnotetext{
${ }^{1}$ Zgodnie z postanowieniami ustawy z dnia 11.04 .2003 r. o kształtowaniu ustroju rolnego (DzU $\mathrm{Nr} 64$ z 2003 r., poz. 592), która weszła w życie dnia 16.07.2003 r., Agencja Własności Rolnej Skarbu Państwa (AWRSP) zmieniła nazwę na: Agencja Nieruchomości Rolnych (ANR).
} 
$\mathrm{w}$ administrowanie, $\mathrm{w}$ ramach którego zarządzający działa $\mathrm{w}$ imieniu i na rachunek Agencji. Administrowanie, choć jest jedną $z$ ustawowych form zagospodarowania mienia, z punktu widzenia programu jego prywatyzacji jest rozwiązaniem tymczasowym.

Celem badań było przeprowadzenie analizy porównawczej organizacji i wydajności jednostkowych produkcji roślinnej i zwierzęcej oraz efektywności wykorzystania czynników wytwórczych ${ }^{2}$ w gospodarstwach rolniczych o różnych formach organizacyjno-prawnych działalności. Badaniem objęto 95 gospodarstw indywidualnych położonych w makroregionie środkowo-zachodnim według regionalizacji wykorzystywanej przez Instytut Ekonomiki Rolnictwa i Gospodarki Żywnościowej (IERiGŻ). Wybrano wszystkie gospodarstwa prowadzące nieprzerwanie rachunkowość rolną w okresie lat 1997-2000. Analizą zostały objęte gospodarstwa o powierzchni powyżej 15 ha użytków rolnych (UR). Wprowadzono ograniczenie minimalnej powierzchni gospodarstwa, bowiem w mniejszych skala produkcji jest zbyt mała, jak również często wpływ pozarolniczych dochodów gospodarstwa zniekształca rzeczywiste efekty produkcyjne. Badania zostały również przeprowadzone w wielkoobszarowych gospodarstwach (przedsiębiorstwach) rolniczych o powierzchni powyżej 500 ha UR w ww. latach. Analizowano trzy grupy gospodarstw: dzierżawców ziemi od AWRSP (21 gospodarstw dzierżawionych - gospodarstwa, które udostępniły informacje lub zostały pozytywnie zweryfikowane pod względem wiarygodności źródłowych informacji liczbowych), gospodarstwa administrowane (37 gospodarstw - wszystkie gospodarstwa) oraz jednoosobowe spółki AWRSP (10 spółek - wszystkie gospodarstwa), położonych w makroregionie środkowozachodnim. Do badań przyjęto zatem łącznie 68 gospodarstw (przedsiębiorstw) rolniczych, dobranych w sposób celowy lub obejmujących wszystkie gospodarstwa położone na terenie badanego makroregionu. Za podstawę wyboru przedsiębiorstw do badań posłużył wykaz dzierżawców nieruchomości przyjętych do Zasobu Skarbu Państwa przez OT AWRSP w Poznaniu i Bydgoszczy oraz wykaz gospodarstw pozostających w administrowaniu i spółek komercyjnych ze $100 \%$ udziałem AWRSP. Przedmiotem badań były gospodarstwa (przedsiębiorstwa) rolnicze o dużym zróżnicowaniu w powierzchni użyt-

\footnotetext{
${ }^{2} \mathrm{~W}$ opracowaniu $\mathrm{z}$ czynników wytwórczych zasadniczą uwage zwrócono na analize zasobów ziemi i pracy, natomiast zagadnienia kapitału (własnego i obcego) były omówione przez autora w następujących opracowaniach:

Wasilewski M., 2003: Sprawozdawczość finansowa w analizie wskaźnikowej gospodarstw rolniczych. W: Sprawozdawczość i rewizja finansowa w procesie podnoszenia kwalifikacji kadry menedżerskiej. Wydawnictwo AE w Krakowie, Kraków.

Wasilewski M., 2004: Kapitałowe uwarunkowania efektywności gospodarstw indywidualnych. Roczniki Nauk Rolniczych, Seria G-Ekonomika Rolnictwa, t. 91, z. 1, Warszawa.
} 
ków rolnych i przez to skali działalności (produkcji). Ziętara [1998] określa gospodarstwo rolnicze jako jednostkę produkcyjna, wyodrębnioną pod względem organizacyjnym, stanowiącą zespół trzech czynników produkcji: ziemi, pracy i kapitał. Wyodrębnienie organizacyjne oznacza, że gospodarstwo posiada wydzieloną ziemię, środki produkcji i pracę. Stanowi więc jednostkę techniczno-organizacyjna, ukierunkowaną na wytwarzanie produktów rolniczych. $Z$ kolei przedsiębiorstwo rolnicze stanowi jednostkę gospodarczą wyodrębnioną nie tylko pod względem organizacyjnym, lecz także ekonomicznym i prawnym, nastawioną na wytwarzanie produktów i usług rolniczych w celu ich sprzedaży. W przedsiębiorstwach produkcja ma charakter głównie towarowy. Mówiąc o gospodarstwie nie wnikamy w charakter produkcji, czy przeznaczona jest na samozaopatrzenie, czy też na sprzedaż. Wspólną cechą omawianych form organizacyjnych jest wykorzystywanie do produkcji tych samych czynników wytwórczych, których zaangażowanie może przynosić określone wyniki produkcyjne, będące przedmiotem analizy w opracowaniu.

\section{Wyniki badań}

Gospodarstwa indywidualne znacznie odbiegały pod względem powierzchni ogólnej, a w tym użytków rolnych, od pozostałych grup gospodarstw (tab. 1). Wynika to m.in. $\mathrm{z}$ historycznych uwarunkowań ich funkcjonowania i wcześniej ustalonych relacji obszarowych między gospodarstwami indywidualnymi i wielkoobszarowymi, powstałymi po dawnych PGR-ach. Niemniej jednak analiza zmian powierzchni gospodarstw pozwoliła na określenie tendencji, jakie wystapiły w latach 1997-2000 w gospodarstwach mało- i wielkoobszarowych. Stwierdzono, że średnia powierzchnia użytków rolnych gospodarstw indywidualnych zwiększyła się do 37,1 ha w 2000 roku, tj. o 9,1\%. Przyrost średniej powierzchni gruntów ornych w tych gospodarstwach był wyższy i wyniósł $10,7 \%$. Zaznaczył się natomiast spadek powierzchni trwałych użytków zielonych (TUZ), najbardziej widoczny przy pastwiskach (o 16,7\%).

We wszystkich grupach gospodarstw wielkoobszarowych nastapił spadek powierzchni użytków rolnych. Największa powierzchnia występowała w spółkach AWRSP, która w 2000 roku wynosiła średnio 2665,2 ha, z tendencją malejąca (o 12,7\%). Największe zmiany obszarowe wystapiły w przypadku TUZ, bowiem powierzchnia łąk zmniejszyła się o $28,6 \%$, a powierzchnia pastwisk zwiększyła się o $17,8 \%$. W gospodarstwach dzierżawców przeciętna powierzchnia użytków rolnych zmniejszyła się do 1496,6 ha w 2000 r., tylko nieznacznie bardziej niż w spółkach AWRSP. Zbliżone tendencje i tempo zmian 
dotyczyły także gruntów ornych. Zauważalny był znaczny spadek powierzchni TUZ w gospodarstwach dzierżawców, większy niż w spółkach AWRSP. Powierzchnia użytków rolnych gospodarstw administrowanych była najmniejsza $\mathrm{z}$ analizowanych grup gospodarstw wielkoobszarowych (1009,2 ha w $1999 \mathrm{r}$.) i zmniejszyła się o 10,0\%. Jednocześnie w tej grupie gospodarstw nie występowały tak jednorodne zależności przy powierzchni TUZ.

\section{Tabela 1}

Zasoby ziemi w gospodarstwach (ha)

\begin{tabular}{|c|c|c|c|c|c|c|c|c|}
\hline \multicolumn{2}{|c|}{$\begin{array}{l}\text { Grupy gospo- } \\
\text { darstw } \\
\text { Lata }\end{array}$} & $\begin{array}{c}\text { Po- } \\
\text { wierz- } \\
\text { chnia } \\
\text { ogółem }\end{array}$ & $\begin{array}{l}\text { Użytki } \\
\text { rolne }\end{array}$ & $\begin{array}{l}\text { Grunty } \\
\text { orne }\end{array}$ & $\begin{array}{l}\text { Sady } \\
\text { i szkółki }\end{array}$ & $\begin{array}{l}\text { Łąki } \\
\text { trwałe }\end{array}$ & $\begin{array}{l}\text { Pastwi- } \\
\text { ska } \\
\text { trwale }\end{array}$ & Inne \\
\hline \multirow{5}{*}{ 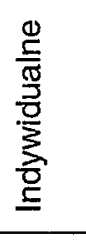 } & 1997 & 36,4 & 34,0 & 30,7 & 0,2 & 2,5 & 0,6 & 2,4 \\
\hline & 1998 & 38,5 & 36,4 & 32,8 & 0,2 & 2,9 & 0,5 & 2,1 \\
\hline & 1999 & 39,5 & 37,1 & 33,8 & 0,2 & 2,6 & 0,5 & 2,4 \\
\hline & 2000 & 39,4 & 37,1 & 34,0 & 0,2 & 2,4 & 0,5 & 2,3 \\
\hline & $00 / 97(\%)$ & 108,2 & 109,1 & 110,7 & 100,0 & 96,0 & 83,3 & 95,8 \\
\hline \\
\hline \multirow{5}{*}{ 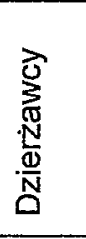 } & 997 & 1916,5 & 1819,3 & 1662,7 & 7,3 & 112,0 & 37,3 & 97,2 \\
\hline & 1998 & 1798,2 & 1704,0 & 1574,1 & 5,8 & 89,2 & 34, & 94,2 \\
\hline & 1999 & 1700,3 & 1619,4 & 1507,4 & 5,5 & 72,1 & 34,4 & 80,9 \\
\hline & 2000 & 1570,7 & 1496,6 & 1407,8 & 5,5 & 55,6 & 27,7 & 74,1 \\
\hline & $00 / 97(\%)$ & 82,0 & 82,3 & 84,7 & 75,3 & 49,6 & 74,3 & 76,2 \\
\hline & & & & & & & & \\
\hline \multirow{5}{*}{ 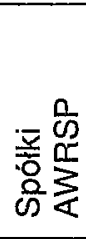 } & & 3216,2 & 3053,7 & 2778,1 & 37,3 & 158,6 & 79,7 & 162,5 \\
\hline & 1998 & 3239,4 & 3062,9 & 2792,4 & 35,6 & 159,4 & 75,5 & 176,5 \\
\hline & 1999 & 3119,2 & 2944,3 & 2683,2 & 35,2 & 129,7 & 96,2 & 174,9 \\
\hline & 2000 & 2798,2 & 2665,2 & 2421,7 & 36,4 & 113,2 & 93,9 & 133,0 \\
\hline & $00 / 97(\%)$ & 87,0 & 87,3 & 87,2 & 97,6 & 71,4 & 117,8 & 81,8 \\
\hline \\
\hline \multirow{4}{*}{ 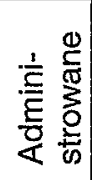 } & 1997 & 1144,0 & 1121,7 & 1034,1 & 3,0 & 60,2 & 24,4 & 22,3 \\
\hline & 1998 & 1206,4 & 1111,8 & 1053,2 & 9,8 & 37,0 & 11,8 & 94,6 \\
\hline & 1999 & 1072,4 & 1009,2 & 924,0 & 12,1 & 51,0 & 22,1 & 63,2 \\
\hline & $99 / 97(\%)$ & 93,7 & 90,0 & 89,4 & 403,3 & 84,7 & 90,6 & 283,4 \\
\hline
\end{tabular}

Źródło: Badania własne. 
$\mathrm{Na}$ rysunku 1 przedstawiono kształtowanie się zatrudnienia $\mathrm{w}$ gospodarstwach $w$ osobach ( $w$ gospodarstwach indywidualnych $w$ jednostkach pełnosprawnych siły roboczej - jpsr ${ }^{3}$ ) w przeliczeniu na 100 ha UR. Stwierdzono spadek zatrudnienia w poszczególnych gospodarstwach, największy u dzierżawców i w spółkach AWRSP, odpowiednio o 26,2\% i 21,9\%. Najmniejsze zmiany zatrudnienia dotyczyły gospodarstw indywidualnych. Wynika to z ich rodzinnego charakteru i korzystania tylko w niewielkim stopniu z najemnej siły roboczej. W gospodarstwach tych było najwyższe zatrudnienie na 100 ha UR, które zmniejszyło się w 2000 r. o 14,1\% (z 8,5 osób/100 ha UR). Spadek zatrudnienia $w$ gospodarstwach indywidualnych powiazany był ze wzrostem powierzchni UR, podczas gdy w pozostałych grupach gospodarstw spadkowi liczby osób zatrudnionych towarzyszyło także zmniejszenie powierzchni UR. Najniższym poziomem zatrudnienia i tempem jego spadku charakteryzowały się gospodarstwa dzierżawców, w których zmniejszyło się ono do 4,8 osób/100 ha UR w $2000 \mathrm{r}$. Zatrudnienie w spółkach AWRSP uległo zmniejszeniu w badanych latach do 5,7 osób/100 ha UR w 2000 r. Jedynie w gospodarstwach administrowanych zatrudnienie nieznacznie zwiększyło się (do 6,0 osób/100 ha UR w 1999 r.), co należy wiązać z większym tempem zmniejszania powierzchni UR niż spadku zatrudnienia ogółem w tej grupie gospodarstw.

W strukturze upraw we wszystkich gospodarstwach dominowały zboża, których najwyższy udział w $2000 \mathrm{r}$. wystapił w gospodarstwach indywidualnych $(69,4 \%)$, podczas gdy najniższy był w spółkach AWRSP $(51,5 \%)$ (rys. 2). Najwyższy udział zbóż w strukturze zasiewów dotyczył gospodarstw administrowanych w 1997 r. (77,5\%). Gospodarstwa te charakteryzowały się ponadto najwyższym udziałem pszenicy w strukturze zasiewów (34\% w 1997 r.). W $2000 \mathrm{r}$. natomiast najwyższy udział pszenicy był w gospodarstwach dzierżawców $(31,0 \%)$. Najniższy udział pszenicy w strukturze zasiewów w analizowanych latach występował w gospodarstwach indywidualnych (22-25\%). Gospodarstwa te natomiast zdecydowanie dominowały pod względem udziału ziemniaków w strukturze zasiewów, które miały marginalne znaczenie w pozostałych grupach gospodarstw. Wynika to $z$ faktu niestosowania przez gospodarstwa duże ziemniaków jako paszy dla zwierząt (głównie trzody chlewnej), podczas gdy $w$ gospodarstwach indywidualnych wykorzystanie to jest znacznie częstsze i większe. Udział w strukturze zasiewów buraków cukrowych w ostatnim analizowanym roku był najwyższy $w$ gospodarstwach indywidualnych (7,6\%), podczas gdy w spółkach AWRSP w latach 1999-2000 zaznaczył się

\footnotetext{
${ }^{3}$ Przyjęto następujące współczynniki przeliczeniowe (wsp.p.) osób młodocianych, osób w wieku produkcyjnym i poprodukcyjnym (opartych na kryterium fizjologicznym), przyjmując za podstawę dane źródłowe $z$ rachunkowości IERiGŻ: do 14 lat - wsp.p. 0,4, 15-60 lat - wsp.p. 0,9, powyżej 60 lat-wsp.p. 0,4.
} 


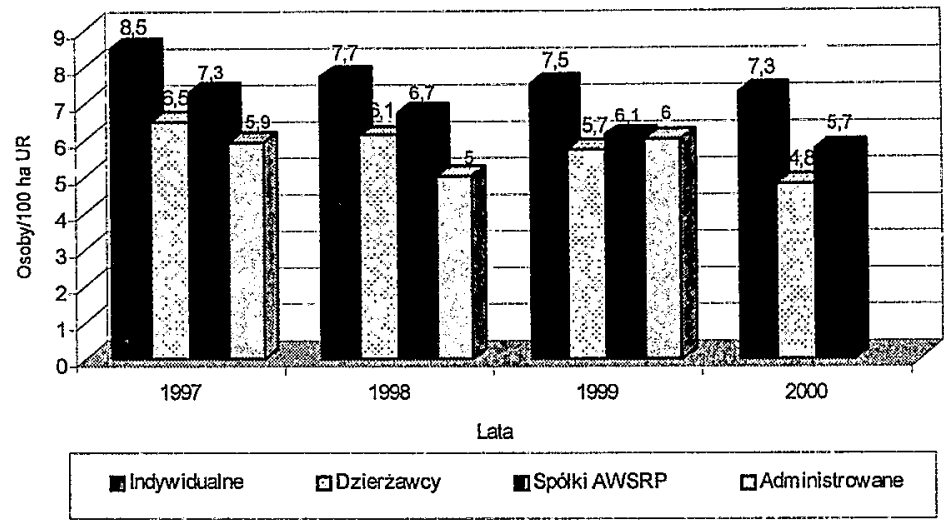

\section{Rysunek 1}

Zatrudnienie $w$ gospodarstwach

Źródło: Badania własne.

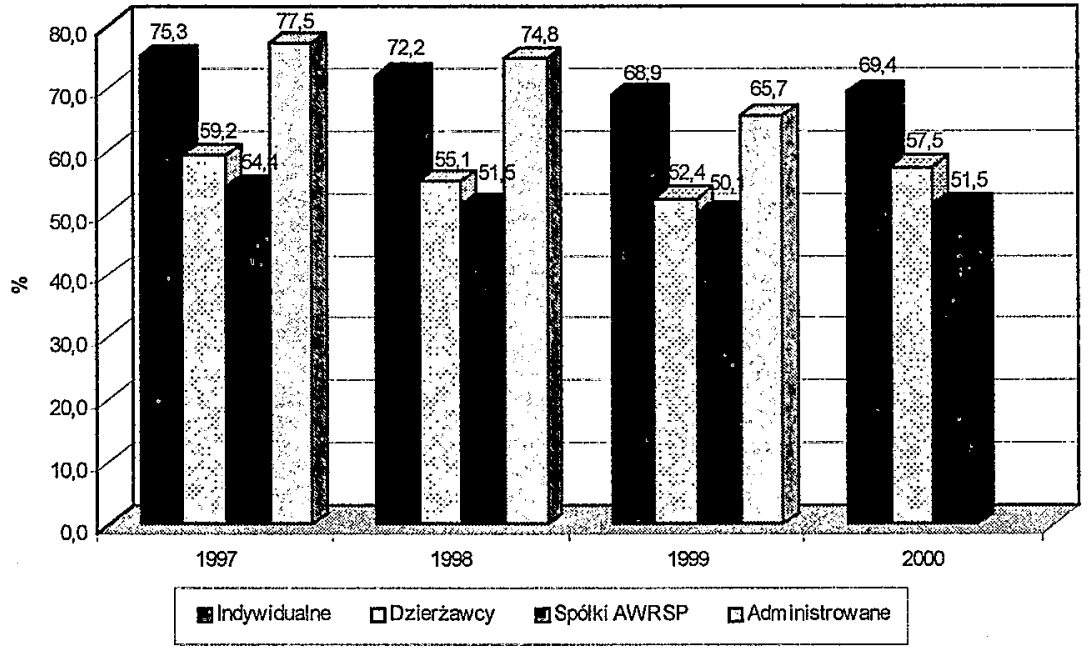

\section{Rysunek 2}

Udział zbóż w strukturze zasiewów roślin uprawnych Źródło: Badania własne.

spadek udziału do około $6,8 \%$. W gospodarstwach dzierżawców i administrowanych udział buraków cukrowych w strukturze zasiewów był jeszcze niższy. Pod względem udziału w strukturze upraw rzepaku i rzepiku dominowały gospodarstwa dzierżawców i spółki AWRSP. W latach 1997-1999 najwyższy udział tych upraw wystąpił w gospodarstwach dzierżawców $(18,6 \%)$, natomiast w 2000 r. w spółkach AWRSP (16,8\%). W gospodarstwach indywidualnych 
udział uprawy rzepaku i rzepiku nie przekroczył 8,8\%. W spółkach AWRSP widoczny był znacznie. większy udział w strukturze zasiewów okopowych pastewnych (7-8\%), podczas gdy w pozostałych grupach gospodarstw ksztaltował się na poziomie niższym niż $0,7 \%$.

Najbardziej stabilny poziom zużycia nawozów występował w spółkach AWRSP (205-208 kg NPK/ha UR) (rys. 3). Zbliżone zależności były także w gospodarstwach dzierżawców, przy czym przeciętny poziom nawożenia był nieznacznie wyższy niż w spółkach AWRSP. W tej grupie gospodarstw w $1997 \mathrm{r}$. wystapił także najwyższy poziom nawożenia, który wyniósł $215,6 \mathrm{~kg}$ NPK/ha UR. W 2000 r. najwyższą wielkością nawożenia charakteryzowały się gospodarstwa indywidualne (215 kg NPK/ha UR). Reasumując, można stwierdzić, że różnice w poziomie nawożenia między analizowanymi grupami gospodarstw były niewielkie, zatem potencjalny wpływ nawożenia na poziom plonów był zbliżony.

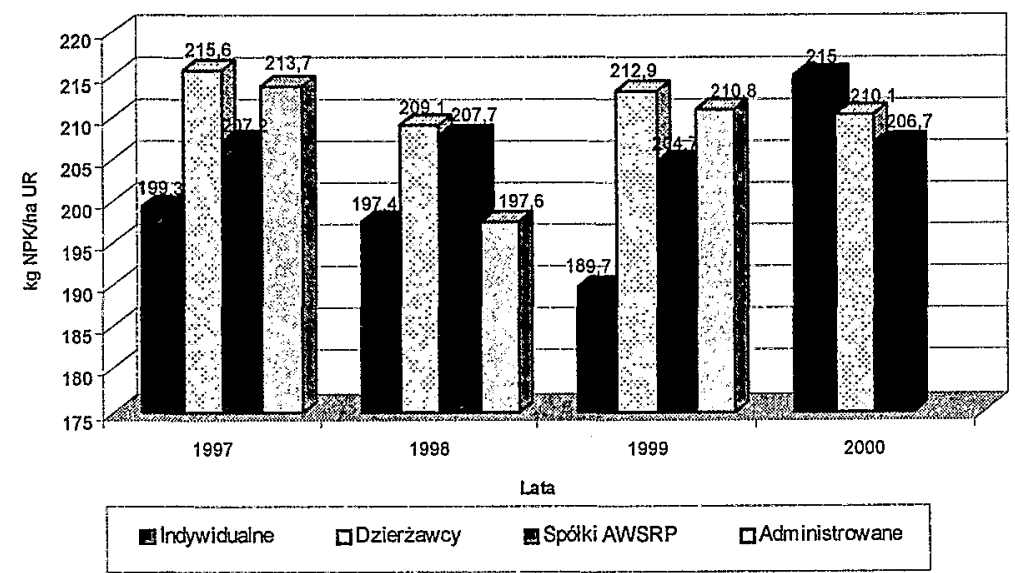

\section{Rysunek 3}

Zużycie nawozów mineralnych

Żródło: Badania własne.

We wszystkich grupach gospodarstw nie stwierdzono jednolitych zależności ksztaltowania się plonów upraw w ujęciu czasowym (dynamicznym) (rys. 4). Średnie plony zbóż były najwyższe w spółkach AWRSP, niewiele niższe wystapiły w gospodarstwach dzierżawców, a najniższe w gospodarstwach administrowanych. Najwyższy średni plon zbóż wystapił w spółkach AWRSP w 1998 r. (52,1 dt/ha), podczas gdy maksymalny w gospodarstwach indywidualnych wyniósł 42,3 dt/ha w 1999 r. Zróżnicowanie plonów pszenicy między analizowanymi grupami gospodarstw było mniejsze, a najwyższy plon został 
osiagnięty w gospodarstwach dzierżawców $(54,6 \mathrm{dt} / \mathrm{ha})$. W przypadku plonów ziemniaków zauważalny był ich wyższy poziom we wszystkich analizowanych grupach gospodarstw w latach 1998 i 2000 , podczas gdy w pozostałych był znacznie niższy. Najwyższy plon ziemniaków wystąpił w gospodarstwach dzierżawców w $1998 \mathrm{r}$. i wynosił 287,2 dt/ha, a najniższy w $1999 \mathrm{r}$. w gospodarstwach administrowanych $(168,3 \mathrm{dt} / \mathrm{ha})$. Gospodarstwa te w pozostałych latach także charakteryzowały się znacznie niższymi plonami od pozostałych grup gospodarstw. Zbliżone zależności jak przy plonach ziemniaków wystapiły także w przypadku uprawy buraków cukrowych. Zauważalny był także fakt uzyskiwania przez gospodarstwa administrowane najniższych plonów buraków cukrowych. Najwyższy plon buraków cukrowych został osiagnięty w $2000 \mathrm{r}$. w gospodarstwach dzierżawców $(562,6 \mathrm{dt} / \mathrm{ha})$. Plony rzepaku i rzepiku w gospodarstwach były zbliżone. W większości lat (z wyjątkiem 1999 r.) najwyższymi plonami tych upraw charakteryzowały się spółki AWRSP, a najniższymi gospodarstwa administrowane. Najwyższy średni plon rzepaku i rzepiku wystappił w spółkach AWRSP w $1998 \mathrm{r}$. i wynosił 30,7 dt/ha. W większości przypadków, porównując lata 1997 i 2000, nastąpił wzrost plonów analizowanych upraw, chociaż nie była to zawsze jednorodna tendencja rosnąca. Można stwierdzić, że poziom plonów ważniejszych upraw w gospodarstwach byl zadowalający, znacznie przewyższający średnie krajowe.

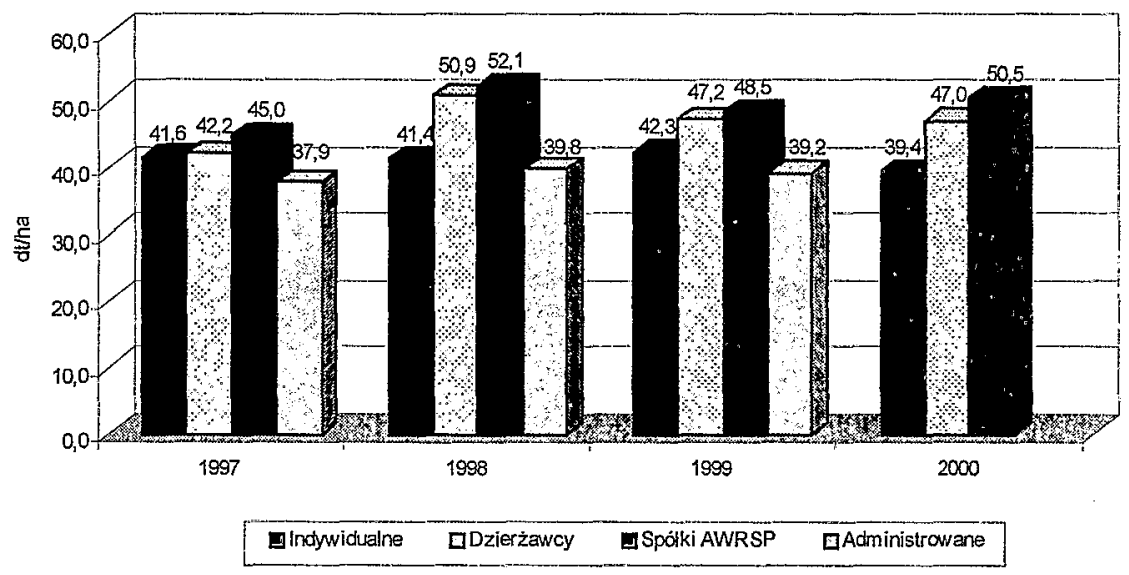

Rysunek 4

Plony zbóż

Źródlo: Badania własne. 
$\mathrm{Na}$ rysunku 5 przedstawiono obsadę zwierząt gospodarskich w analizowanych grupach gospodarstw. Najwyższą obsadą charakteryzowały się gospodarstwa indywidualne, z tendencją malejąca do $69,8 \mathrm{SD} / 100$ ha UR w $2000 \mathrm{r}$. Relatywnie wysoka obsada inwentarza żywego wystapiła także w gospodarstwach administrowanych. Największą zmiana przyrostu obsady inwentarza żywego (o $36,2 \%$ ) charakteryzowały się gospodarstwa dzierżawców (do 60,9 SD/100 ha UR w 2000 r.), podczas gdy w pozostałych grupach gospodarstw zaznaczył się jej spadek, największy w gospodarstwach administrowanych (o 14,8\%). W zakresie analizy obsady rodzajowej, tzn. bydła, trzody i owiec, widoczne były zasadnicze różnice między gospodarstwami wielkoobszarowymi a indywidualnymi. W gospodarstwach indywidualnych w obsadzie dominowała trzoda chlewna, podczas gdy w pozostałych grupach gospodarstw bydło. Najwyższa obsada bydła wystapiła w spółkach AWRSP. Podkreślenia wymaga fakt znacznego wzrostu obsady bydła w gospodarstwach dzierżawców, do 39,6 SD/100 ha UR w 2000 r., tj. o 62,3\%. Najbardziej stabilna obsada bydła występowała $\mathrm{w}$ gospodarstwach indywidualnych. W gospodarstwach tych obsada trzody chlewnej była najwyższa, podczas gdy najniższa w spółkach AWRSP. Tylko w gospodarstwach dzierżawców nastapiło zwiększenie obsady trzody chlewnej między skrajnymi latami analizowanego okresu (o 9,6\%). Cechą wspólną oceny poziomu obsady zwierząt $w$ gospodarstwach było marginalne znaczenie owiec.

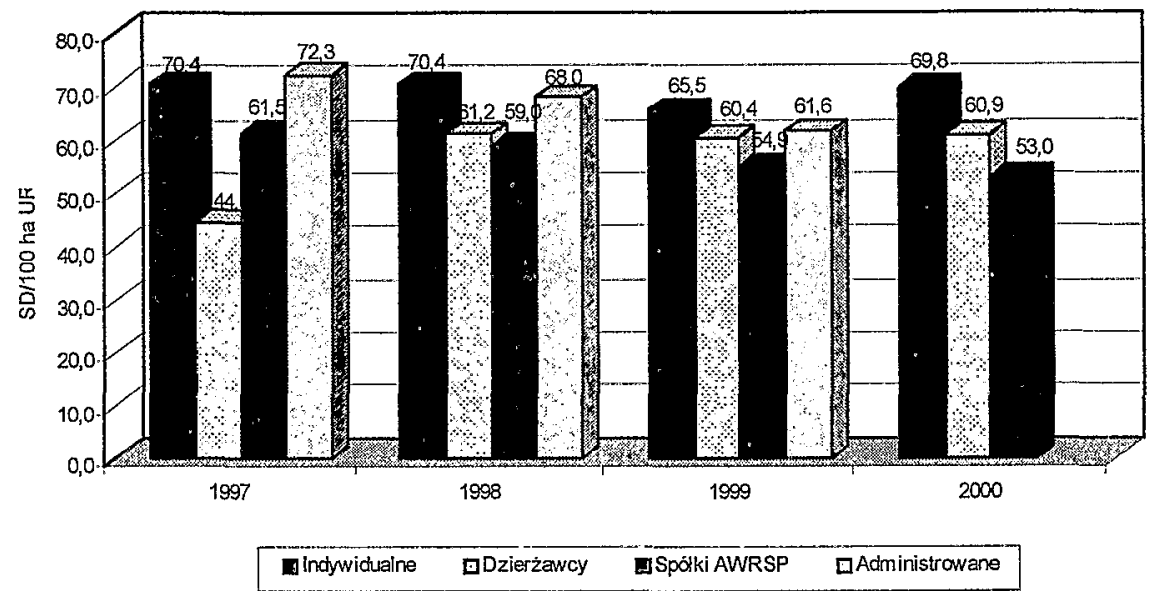

Rysunek 5

Obsada zwierząt ogółem w gospodarstwach Żródło: Badania własne. 
W tabeli 2 przedstawiono podstawowe wydajności jednostkowe produkcji zwierzęcej. Stwierdzono, że najwyższą mlecznością krów charakteryzowały się spółki AWRSP, z tendencją rosnąca do 4915,5 l od jednej krowy w $2000 \mathrm{r}$. Była to najwyższa mleczność jednej krowy w analizowanych grupach gospodarstw. Niewiele niższy poziom mleczności krów był w gospodarstwach administrowanych. Najniższa mleczność krów wystąpiła w gospodarstwach indywidualnych (do 4120,4 litrów w 2000 r.). Wprawdzie w ciagu dwóch ostatnich analizowanych lat zwiększyła się o $4,5 \%$, niemniej jednak najwyższa mleczność w gospodarstwach indywidualnych była niższa aż o 794,91 od najwyższej mleczności w spółkach AWRSP. Spadkowa tendencja mleczności krów wystąpiła w gospodarstwach dzierżawców. Prośność jednej maciory była najwyższa w gospodarstwach indywidualnych (19-20 prosiąt). Była ona nieco niższa $\mathrm{w}$ gospodarstwach dzierżawców, natomiast najniższa wystapiła $\mathrm{w}$ gospodarstwach administrowanych w 1998 r. (13,4 prosiąt od jednej maciory). Pod względem wydajności wełny od jednej owcy między analizowanymi grupami gospodarstw nie występowały znaczące różnice.

\section{Tabela 2}

Wydajności jednostkowe produkcji zwierzęcej

\begin{tabular}{|c|c|c|c|c|}
\hline Grupy gospodarstw & Lata & $\begin{array}{c}\text { Mleczność } \\
\text { krowy } \\
\text { l/rok }\end{array}$ & $\begin{array}{l}\text { Prośność } \\
1 \text { maciory } \\
\text { (szt.) }\end{array}$ & $\begin{array}{l}\text { Wydajność } \\
\text { wełny od } \\
1 \text { owcy }(\mathrm{kg})\end{array}$ \\
\hline \multirow[t]{5}{*}{ Indywidualne } & 1997 & 4026,4 & 19,1 & 4,6 \\
\hline & 1998 & 4119,5 & 20,1 & 5,0 \\
\hline & 1999 & 3943,8 & 19,9 & 5,2 \\
\hline & 2000 & 4120,4 & 19,3 & 4,0 \\
\hline & $00 / 97(\%)$ & 102,3 & 101,0 & 87,0 \\
\hline \multirow[t]{5}{*}{ Dzierżawcy } & 1997 & 4328,1 & 18,7 & 4,2 \\
\hline & 1998 & 4252,7 & 17,3 & 4,3 \\
\hline & 1999 & 4127,3 & 17,9 & 4,9 \\
\hline & 2000 & 4173,8 & 18,1 & 4,4 \\
\hline & $00 / 97(\%)$ & 96,4 & 96,8 & 104,8 \\
\hline \multirow[t]{5}{*}{ Spółki AWRSP } & 1997 & 4707,8 & 16,8 & 3,9 \\
\hline & 1998 & 4899,1 & 17,1 & 4,2 \\
\hline & 1999 & 4898,0 & 16,5 & 3,5 \\
\hline & 2000 & 4915,3 & 17,3 & 4,1 \\
\hline & $00 / 97(\%)$ & 104,4 & 103,0 & 105,1 \\
\hline \multirow[t]{4}{*}{ Administrowane } & 1997 & 4130,0 & 16,9 & 4,7 \\
\hline & 1998 & 4891,0 & 13,4 & 4,2 \\
\hline & 1999 & 4725,0 & 15,4 & 4,0 \\
\hline & $99 / 97(\%)$ & 109,1 & 91,1 & 85,1 \\
\hline
\end{tabular}

Žródło: Badania wlasne. 
Na rysunku 6 przedstawiono kształtowanie się wskaźnika zyskowności (dochodowości) ziemi, obliczanego jako relacja zysku netto (dochodu rolniczego w gospodarstwach indywidualnych) do powierzchni użytków rolnych. We wszystkich analizowanych latach gospodarstwa indywidualne charakteryzowały się dodatnią wielkością wskaźnika, co świadczy o rentowności działalności. Należy mieć jednak na uwadze różnicę w formule obliczeń kategorii dochodu rolniczego oraz zysku netto, bowiem nie odejmuje się $w$ gospodarstwach indywidualnych kosztów pracy własnej rolnika i jego rodziny ${ }^{4}$. Dochód ten stanowi korzyść rolnika $\mathrm{z}$ tytułu własnej pracy i zarządzania gospodarstwem, a także $z$ tytułu zaangażowania własnego kapitału do działalności gospodarstwa. Gospodarstwa administrowane we wszystkich badanych latach ponosity straty, zatem dochodowość ziemi była ujemna. W gospodarstwach dzierżawców dochodowość dodatnia wystapiła jedynie w latach 1997 i 2000 , przy czym jej poziom był niski. Najniższy wskaźnik dochodowość ziemi wystapił w spółkach AWRSP (-227,7 zt/ha UR), a jedynie w $1997 \mathrm{r}$. jednostki te były rentowne, ale na bardzo niskim poziomie.

Zależności w zakresie społecznej wydajności pracy, określonej jako relacja zysku netto (dochodu rolniczego) do liczby zatrudnionych w przeliczeniu na pełne etaty ( $w$ gospodarstwach indywidualnych $w$ jpsr), były zbliżone jak w przypadku wskaźnika dochodowości (zyskowności) ziemi (rys. 7). Najwyższy wskaźnik społecznej wydajności pracy wystapił w gospodarstwach indywidualnych w 2000 r. (15 245,8 zł/osobę). Stwierdzono, że gospodarstwa dzierżawców

\footnotetext{
${ }^{4}$ Do obliczeń przyjęto kategorię dochodu rolniczego netto, który określa nadwyżkę wartości produkcji nad kosztami rzeczywistymi (bezpośrednimi i pośrednimi - łącznie z amortyzacja). Wyceniajacc jednak koszt pracy własnej rolnika i jego rodziny przy pracach rolnych i inwestycyjnych, można obliczyć dochód rolniczy formułą zbliżony do kategorii zysku netto w jednostkach prowadzących pełną rachunkowość, na podstawie ustawy o rachunkowości. Do celów opracowania zostanie przyjęte pojęcie zysku kalkulacyjnego (zysk z kapitału i zarządzania). Koszt pracy rolnika i jego rodziny został oszacowany według stawki parytetowej za 1 godzinę. Stawkę tą wyliczono na podstawie średniorocznego wynagrodzenia netto $\mathrm{w}$ całej gospodarce narodowej wedhug danych GUS, przyjmując, że nominalny czas pracy jednego pełnozatrudnionego $\mathrm{w}$ rolnictwie indywidualnym wynosi w ciagu roku 2200 godzin. W 2000 r. parytetowa stawka za 1 godzinę pracy wynosiła $6,99 \mathrm{zl}$. W roku tym przepracowano łącznie średnio w gospodarstwie 4417,7 godziny, co $w$ przeliczeniu na 1 ha UR wynosi 119,1 godziny. Zatem koszty pracy własnej rolnika i rodziny wyniosły łącznie $832,3 \mathrm{zl} /$ ha UR. Uwzględniając tę wielkość zysk kalkulacyjny w 2000 r. wyniósłby 277,2 zł/ha UR. Gospodarstwa te, średnio jako badana zbiorowość, były zatem nadal dochodowe. W latach 1997-1999 natomiast wielkość zysku kalkulacyjnego w gospodarstwach wynosiła odpowiednio: $358 \mathrm{z} / / \mathrm{ha}$ UR, 276,5 zt/ha UR oraz $57 \mathrm{z}$ l/ha UR.

${ }^{5}$ Uwzględniając koszty nakładów pracy własnej rolnika i jego rodziny wskaźnik ten w $2000 \mathrm{r}$. wyniósłby $3808,9 \mathrm{z}$ /osobę, podczas gdy w gospodarstwach dzierżawców $1825,3 \mathrm{z}$ /osobę. Gospodarstwa indywidualne były zatem nadal pod tym względem bardziej efektywne niz dzierżawców. W latach 1997-1999 wielkość tego wskaźnika uksztaltowała się na poziomie odpowiednio: $4174,1 \mathrm{zt} /$ osobę, $3594,3 \mathrm{zł} /$ osobę oraz $754,5 \mathrm{zt}$ /osobę.
} 


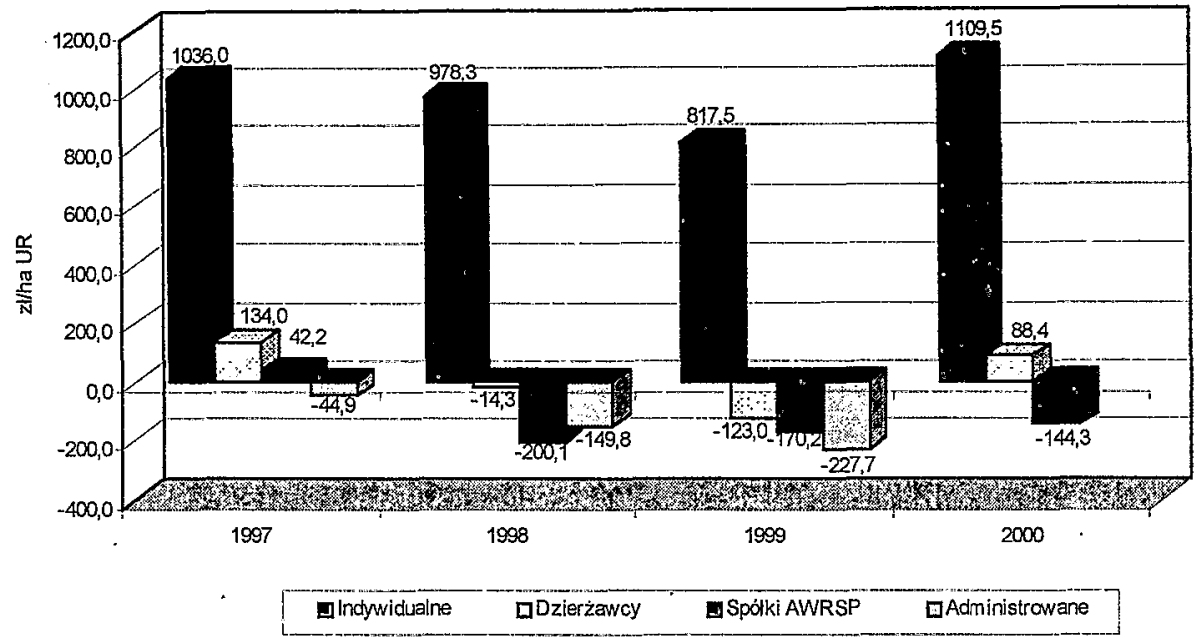

\section{Rysunek 6}

Zyskowność (dochodowość) ziemi

Źródło: badania własne.

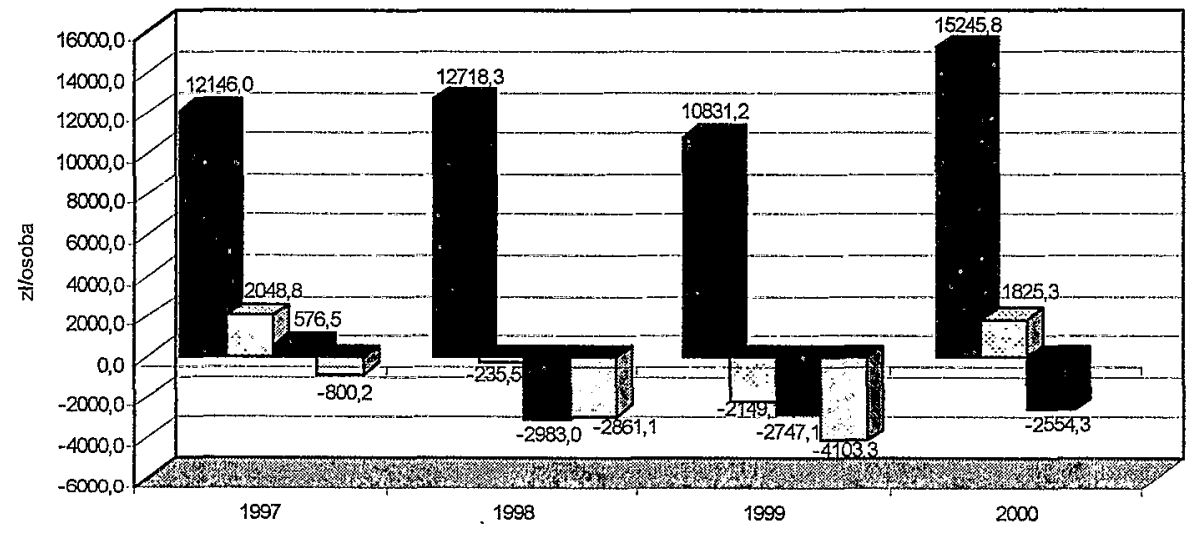

Indywidualne

口Dzierżawcy

Spöiki AWRSP

DAdministrowane

\section{Rysunek 7}

Wydajność społeczna pracy

Źródło: Badania własne. 
charakteryzowały się dodatnią wielkością wskaźnika w dwóch analizowanych latach (1997 i 2000, przy czym w 1998 r. wielkość ujemna była relatywnie niewielka). W spółkach AWRSP w latach 1998-2000 utrzymywała się zbliżona, ujemna wielkość tego wskaźnika.

Gospodarstwa indywidualne charakteryzowały się stabilnym poziomem wskaźnika rentowności kapitału własnego w całym analizowanym okresie $\left(5,1-6,7 \%{ }^{6}\right)$ (rys. 8). Wskaźnik ten został obliczony jako relacja zysku netto (dochodu rolniczego) do wartości kapitału własnego gospodarstwa. Najniższa efektywność wykorzystania kapitału własnego wystapiła w spółkach AWRSP $(-8,8 \%$ w 1998 r.), przy czym podkreślenia wymaga systematyczny wzrost wielkości tego wskaźnika, do poziomu $-5,2 \%$ w $2000 \mathrm{r}$. W gospodarstwach administrowanych następował natomiast systematyczny spadek zyskowności kapitału własnego (w zakresie rentowności ujemnej).

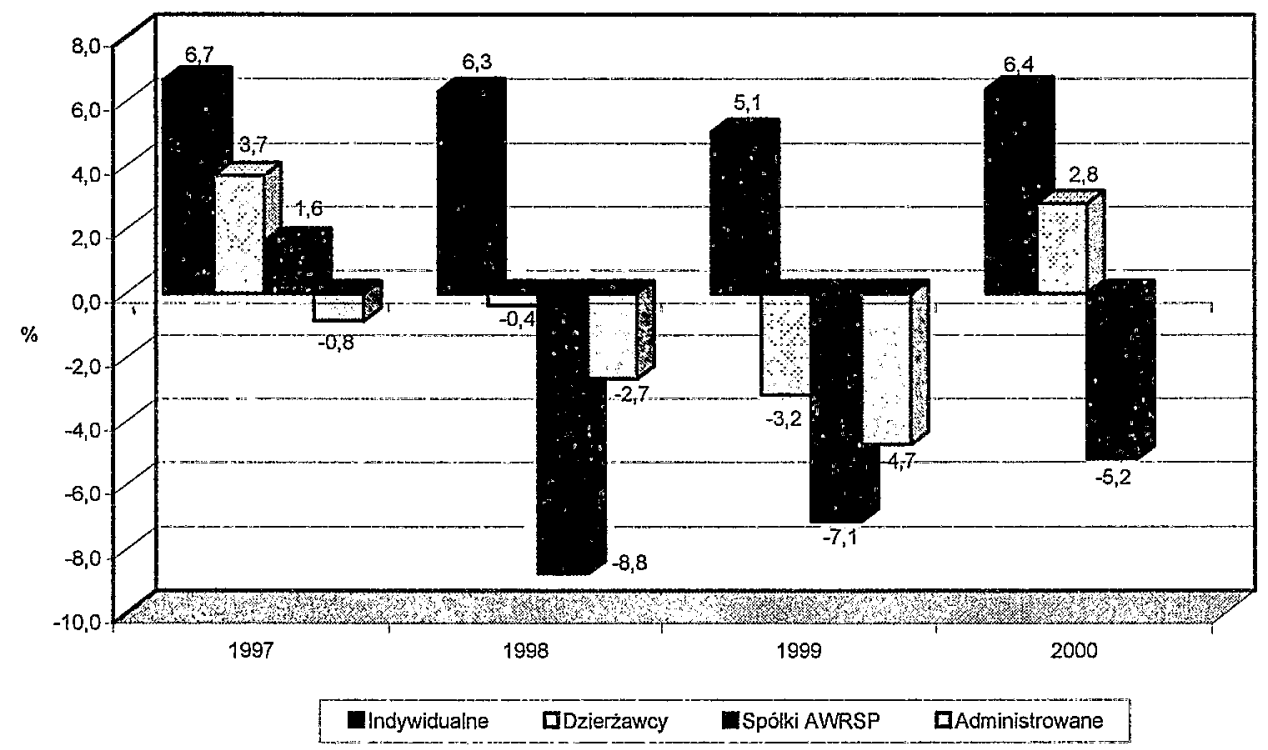

\section{Rysunek 8}

Zyskowność (dochodowość) kapitału własnego Źródło: Badania własne.

\footnotetext{
${ }^{6}$ Uwzględniając koszty nakładów pracy własnej rolnika i jego rodziny wskaźnik ten wyniósłby w 2000 r. $1,6 \%$, podczas gdy w gospodarstwach dzierżawców $2,8 \%$. W gospodarstwach dzierżawców zatem wskaźnik ten był wyższy, co świadczy o efektywniejszym wykorzystaniu kapitału własnego, uwzględniając w gospodarstwach indywidualnych wszystkie poniesione koszty. W latach 1997-1999 w gospodarstwach indywidualnych, po uwzględnieniu kosztów własnej pracy rolnika $\mathrm{i}$ jego rodziny, wskaźnik ten wyniósłby odpowiednio: $2,3 \%, 1,8 \%$ oraz $0,4 \%$.
} 


\section{Wnioski}

W opracowaniu przedstawiono analizę porównawczą organizacji i wydajności jednostkowych produkcji roślinnej i zwierzęcej oraz rentowność wykorzystania czynników wytwórczych w gospodarstwach rolniczych o różnych formach organizacyjno-prawnych działalności. Na podstawie przeprowadzonych badań sformułowano następujące wnioski końcowe.

1. Udział użytków rolnych w powierzchni ogólnej był zbliżony we wszystkich grupach gospodarstw (około 95\%). Powierzchnia UR gospodarstw indywidualnych nieznacznie zwiększyła się, podczas gdy w pozostałych grupach gospodarstw widoczna była tendencja malejąca, najbardziej w gospodarstwach dzierżawców. Może to oznaczać rezygnację części z nich $\mathrm{z}$ dzierżawy ziemi $\mathrm{w}$ wyniku niemożności opłaty czynszu dzierżawnego. Największe obszarowo były spółki AWRSP, a przeciętna powierzchnia gospodarstw dzierżawców była o około 1200 ha mniejsza. Duża powierzchnia spółek umożliwiała ewentualne wykorzystywanie w większym zakresie efektu skali produkcji i rozłożenia na większą ilość wyrobów kosztów stałych. Jednocześnie spółki charakteryzowały się najniższymi zasobami sily roboczej, podczas gdy w gospodarstwach indywidualnych były one najwyższe. Wynika to $\mathrm{z}$ rodzinnego charakteru tych gospodarstw. Dlatego też znaczenia nabiera $\mathrm{w}$ tej grupie gospodarstw określenie faktycznego zaangażowania członków rodziny $w$ pracach rolnych $i$ inwestycyjnych. Największe tempo spadku zasobów siły roboczej wystapiło w gospodarstwach dzierżawców, co świadczy o racjonalizacji poziomu zatrudnienia.

2. Najwyższy udział w strukturze upraw gospodarstw stanowiły zboża, który na ogót, przy tendencji malejącej, najwyższy był w gospodarstwach indywidualnych (około $70 \%$ w 2000 r.), podczas gdy w spółkach AWRSP jedynie około $51 \%$. Świadczy to o niższej intensywności organizacji w gospodarstwach indywidualnych, na ogół spowodowanej koniecznością zaopatrzenia $\mathrm{W}$ pasze treściwe prowadzonej produkcji zwierzęcej (głównie trzody chlewnej). Gospodarstwa indywidualne miały natomiast w strukturze upraw najwyższy udział ziemniaków. Spółki AWRSP charakteryzowały się znacznie wyższym udziałem rzepaku i rzepiku, buraków cukrowych oraz okopowych pastewnych. Poziom plonów zbóż był najwyższy w spółkach AWRSP, a najniższy w gospodarstwach indywidualnych, w których z kolei najwyższe były plony ziemniaków. Najwyższe plony rzepaku i rzepiku uzyskiwały spółki AWRSP, a w gospodarstwach dzierżawców najwyższe efekty wydajności jednostkowych uzyskano w przy- 
padku buraków cukrowych. Gospodarstwa indywidualne charakteryzowały się na ogół najniższym poziomem nawożenia mineralnego, które najbardziej stabilne było w spółkach AWRSP, jednak różnice pod tym względem między gospodarstwami były relatywnie niewielkie. Najwyższa obsada inwentarza żywego wystapiła w gospodarstwach indywidualnych, podczas gdy najniższa (na ogół $\mathrm{z}$ tendencją malejąca) w spółkach AWRSP. W strukturze stada zwierząt $w$ gospodarstwach indywidualnych dominowała trzoda chlewna, podczas gdy w pozostałych grupach gospodarstw bydło. Miało to konsekwencje w wyższym udziale TUZ w tej grupie przedsiębiorstw. Spółki charakteryzowały się także najwyższą mlecznością krów.

3. Gospodarstwa indywidualne, dysponujące mniejszymi zasobami ziemi, prowadziły produkcję o niższej intensywności organizacji produkcji roślinnej, a wyższej produkcji zwierzęcej. Nie występowały natomiast zasadnicze różnice między grupami gospodarstw w uzyskiwanych wydajnościach jednostkowych prowadzonej produkcji (z wyjątkiem mleczności krów). Jedynie gospodarstwa indywidualne charakteryzowały się rentownością działalności $w$ analizowanym okresie, nawet uwzględniając przy obliczaniu dochodu rolniczego parytetowy koszt pracy własnej rolnika i jego rodziny. Oznacza to efektywne wykorzystanie relatywnie wyższych niż w gospodarstwach wielkoobszarowych zasobów siły roboczej. W gospodarstwach administrowanych i spółkach AWRSP wskaźniki obrazujące rentowność ziemi, pracy i kapitału były najniższe (na ogół ujemne), co świadczy o braku efektywności ich wykorzystania, a przez to niewykorzystywaniu efektu skali działalności. Można zatem stwierdzić, że gospodarstwa o prywatnej formie własności (indywidualne i dzierżawcy) efektywniej wykorzystywały posiadane zasoby czynników wytwórczych niż gospodarstwa o formie własności państwowej.

\section{Literatura}

ADAMOWSKI Z., 1981: Podstawy ekonomiki i organizacji przedsiębiorstw rolnych. PWRiL, Warszawa.

GOŁAŚ Z., 2002: Techniki wytwarzania i ich efektywność w indywidualnych gospodarstwach rolnych. Rozprawy Naukowe, zeszyt 327. Wydawnictwo AR w Poznaniu, Poznań.

MANTEUFFEL R., 1984: Ekonomika i organizacja gospodarstwa rolniczego. PWRiL, Warszawa.

URBAN M., 1981: Ekonomika i organizacja gospodarstw rolnych. PWN, Warszawa. 
WASILEWSKI M., 2003: Sprawozdáaczość finansowa w analizie wskaźnikowej gospodarstw rolniczych. W: Sprawozdawczość i rewizja finansowa w procesie podnoszenia kwalifikacji kadry menedżerskiej. Wydawnictwo AE w Krakowie, Kraków.

WASILEWSKI M., 2004: Kapitałowe uwarunkowania efektywności gospodarstw indywidualnych. Roczniki Nauk Rolniczych, Seria G - Ekonomika rolnictwa, tom 91, z. 1, Warszawa.

ZIĘTARA W., OLKO-BAGIEŃSKA T., 1986: Zadania $\mathrm{z}$ analizy działalności gospodarczej i planowania w gospodarstwie rolniczym. PWRiL, Warszawa.

ZIĘTARA W., 1998: Metodyczne aspekty oceny efektywności gospodarowania w rolnictwie. Zeszyty Naukowe SGGW, Ekonomika i Organizacja Gospodarki Żywnościowej, nr 34, Warszawa.

\title{
The Outputs and the Production Organization in Different Organizational and Property Forms of Agricultural Farms
}

\begin{abstract}
In the paper the comparative analysis of the organization and the productivity per unit of the plant and animal production in different organizational and property forms of agricultural farms is presented. The share of agricultural land in total area was similar in all of the farms' groups, the area of agricultural land in private farms increased insignificantly while in another farms it decreased. Those farms were characterized by the lowest area. Companies were characterized by the lowest level of labour force reserves while in private farms those reserves were the highest. In all of the farms' groups cereals dominated in the structure of sown, the most in private farms, and the least in companies owned to AWRSP. The differences between farms as regards fertilizing with mineral fertilizers were not large, and the highest crops of cereals occurred in AWRSP companies. The highest number of livestock occurred in private farms and the lowest in AWRSP companies. In the structure of the herd of animals swine predominated in private farms and in the rest of farms' groups cattle predominated. Private farms were characterized by the highest effectiveness of reserves of resources to the production usage while companies incurred losses.
\end{abstract}

